\title{
SCHNEIDER Henrik
}

\section{TUDÁSMENEDZSMENT \\ A MOBILTÁVKÖZLÉSBEN}

A szerző 2004-ben végezte el mindhárom magyar mobiltávközlési szolgáltatónál a tudásmenedzsment helyzetének felmérését. Az eredmények szerint a magyar mobilszolgáltatóknál a tudásmenedzsment fontos szerepet kap az üzleti folyamatok támogatásában, viszont a kezdeményezések nem egységes programként, hanem jórészt önálló projektekként valósulnak meg. A tudásmenedzsment kezdeményezések legfontosabb motiválója egyértelműen a versenyelőny szerzése, a vállalati tudásmegosztás elterjesztése, az elkülönülten dolgozó egységek (akár vállalatcsoport) közti együttműködés támogatása a vállalati tudás védelme által.

A tudásmenedzsment lényegi változásokon megy át napjainkban, amit az e tudományággal foglalkozók által használt definíciók sokrétűsége is jól illusztrál. Szinte minden szerző előáll egy meghatározással, illeszkedve saját kutatási irányához, és amelyeket itt mind felsorolni szinte lehetetlen feladat lenne. Két, talán „szélsőségesnek” tekinthető példa álljon itt illusztrálandó az óriási különbségeket. Van, ahol tisztán üzleti nézőpontú definícióval találkozunk, mint például: „a szervezeten belül felhalmozott tudás szisztematikus és szervezett felhasználása a teljesítmény növelése érdekében" (KPMG). Van, aki pedig az adat és információ matematikai definíciójából kiindulva állítja, hogy ,,a tudásmenedzsment adatok szisztematikus használata hipotézisek ellenőrzésére", azaz tulajdonképpen ,valószínűségi függvények szabályokba foglalása" (Singpurwalla, 2003: 363.o.). Bár mindkét meghatározásban vannak visszatérő elemek (pl. a rendszerezettség elvárása), mégis más irányból közelítik a kérdést. A sokféleség miatt jelentős külön irodalma van a szerteágazó kutatási irányok összefoglalásának is (Liao, 2003; Fehér, 2002; Schneider, 2004). Nem egyértelmű továbbá a tudásmenedzsment tevékenység határainak meghúzása sem, amire a kapcsolódó társterületek gyakorlati megvalósításakor derül fény. Legjellegzetesebb példa az ügyfélkapcsolat kezelése (elterjedt angol kifejezéssel Customer Relationship Management, rövidítve: CRM). A vállalatok a CRM beruházások általában óriási volumene miatt, jelentős önálló erőforrásokat rendelnek hozzá, és így olyan független CRM rendszerek alakulnak ki, amelyek nem részei az egységes vállalati tudásmenedzsment rendszereknek. (Ez nem azt jelenti, hogy a CRMet ne kezelnék tudásalapú rendszerként, hanem azt, hogy így gyakorlatilag több, jelentős, kvázi-független tudáskezelő kezdeményezés is fut párhuzamosan a vállalatnál.) Ugyanakkor megfigyelhető fordított kialakítás is, ahol a CRM és a tudásmenedzsment tevékenységek tudatos integrálásával valósul meg a két funkció (Gebert et al., 2003).

Bár a vállalati tudástőke kezelésének tudományos alaposságú vizsgálata még szinte tíz évet sem élt meg (az első igazán nagyhatású írások 1994-1995-re datálhatók [Steward, 1994; Nonaka, 1995]), a tudás valódi, értékes erőforrásként való felhasználása széles körben elfogadott és támogatott koncepcióvá vált, amit a gazdag irodalom és az egyre szélesedő gyakorlati felhasználás is igazol.

\section{Felmérés a magyar mobiltávközlési vállalatoknál}

A távközlés jelenleg a folyamatos technológia-beruházások egyik legjellemzőbb színtere (Hwang, 2003). Ezen belül a magyar (illetve általános a középkelet-európai) mobiltávközlési piac az újítások egyik első bevezetőjének számít, sőt volt olyan fejlemény, ahol világelsőséget is szerzett magyar vállalat (például a T-Mobile - akkor még Westel - vezette be a világ 
első kereskedelmi MMS szolgáltatását). A magyar piac világviszonylatban kicsi ugyan, de a mobilpenetráció az EU átlagnak megfelelő, míg ez például az internet penetrációról nem mondható el, ahol még várat magára az áttörés. Így a mobilszolgáltató vállalatok különösen kiszolgáltatottak az állandó technológiaváltási ciklusok okozta tudásnehézségeknek, a technológiai munkatársaktól kezdve, a marketing- és értékesítési tevékenységeken keresztül egészen az ügyfélszolgálati kapcsolatokig. A távközlés különösen érdekes abból a szempontból is, hogy e szektor hat éve még a sereghajtók között szerepelt a tudásmenedzsment alkalmazások területén (Delphi Group, 1998), ez azonban mára drasztikusan megváltozott.

2004 áprilisa és augusztusa között végeztem el a következőkben eredményeiben részletesen bemutatott felmérést a három magyarországi mobilszolgáltatónál. A kidolgozott kérdőívet egy személyes interjú keretében töltötték ki, mivel a kiküldéses módszer átlagos visszaérkezési aránya ilyen kisszámú mintán nem lett volna megfelelő. Az interjúk két körben zajlottak, és egyrészt a tudásmenedzsment területért felelős vezető, másrészt a gyakorlatot részletesen ismerő beosztottak is részt vettek benne. A felmérés eredményeit a vállalatok kérésének megfelelően szigorúan anonimitással - azaz csak a három válasz átlagértékével - mutatom be.

Az eredmények értékelésekor nyilvánvalóan hasznos lett volna egy hasonló mintán elvégzett korábbi felmérés eredményeire is támaszkodni, azonban ilyen - magyar mobiliparág - nem állt rendelkezésre. Megkerestem a 2000 után készült, általános (iparágakon átívelő) felmérésekben megjelölt kapcsolattartókat, azonban végül ezekből az elemzésekből sem állt rendelkezésemre a szükséges, csak erre a szektorra jellemző információ. Az eredmények értelmezéséhez (az interjúkon elhangzott kiegészítő információkon kívül) a következő korábbi felméréseket használtam fel, amelyek valamilyen módon (ha nem száz százalékosan is) kapcsolódhattak:

- Korábbi magyarországi felmérések: itt a sok helyen referált KPMG 2000-s és 2002-es magyarországi felmérés eredményeit használtam, aminek külön érdekessége, hogy az ehhez a kapcsolódó nemzetközi eredmények is rendelkezésre álltak. (KPMG, 2000a; KPMG, 2000b; Stocker, 2003; KPMG 2002;). Az ábrákon és táblázatokban a KPMG felmérési eredményeket majd sorban „2000 magyar”, „2000 nemzetközi”, ,2002 magyar” és „2002 nemzetközi" elnevezéssel tüntetem fel.

- Korábbi, kifejezetten távközlés specifikus felmérés: mindössze egy, kizárólag távközlési cégekkel fog- lalkozó publikus távközlési felmérés érhető el, ami azonban egyrészt hat éve, másrészt az Amerikai Egyesült Államokban készült, tehát jelentősen más piaci körülmények között (Housel, 1999), így ennek felhasználása csak távoli összehasonlítás jellegű azokon területeken, amikre a többi felmérésből nem volt adat.

- Külföldi és nem távközlési specifikus, de megközelitőleg azonos időben zajló felmérések: amelyek jelentősége abban áll, hogy az általam feltérképezett gyakorlati tanulságok vajon mennyire csengenek össze más iparágakban tapasztaltakkal, illetve az elméleti kutatások eredményeivel. Itt a két fő felhasznált felmérés egy pénzügyi szektorban készült (Squier - Snyman, 2004) és egy, a tudásmenedzsmenttel foglalkozó szakemberek bevonásával elvégzett delphi módszertanú felmérés a tudásmenedzsment jelenérôl és jövőjéről (Scholl et al., 2004) volt.

A következtetések levonásánál minden esetben figyelembe kellett venni, hogy milyen eltérések vannak az említett felmérések és az én felmérésem körülményei között, így ezek az összehasonlítások néhol inkább csak érdekes, informatív jelleggel bírnak, egyes esetekben azonban (ahogyan ez az értékelési részben látható), éppen a különbségek figyelembevételével voltak értékes megállapítások.

\section{Eredmények}

\section{A tudásmenedzsment jelenlétének szintje a vállalatoknál}

Mindhárom megkérdezett cég egyértelműen nyilatkozott a tudásmenedzsment létezéséről a vállalatnál, ugyanakkor egyetlen helyen sincs önálló, egész szervezetre érvényes szintű tudásmenedzsment stratégia (illetve konkrétan tudásmenedzsment stratégiai dokumentum). Egyiküknél jelenleg kidolgozás alatt áll, kettő viszont más stratégiák részeként (esetenként a szervezeti egységek hatáskörébe rendelve) kezeli a kérdést, nem is foglalkozva az önálló megjelenítéssel. Ezzel a tendenciával találkozhatunk más aktuális felmérésekben is (Squier - Snyman, 2004; Scholl et al., 2004), amennyiben a tudásmenedzsment nem önálló funkcióként, hanem az általános vállalati folyamtokba épülve segíti a működést. Ezek után nem meglepő tehát az sem, hogy önálló, specializált tudásmenedzsment igazgatóság vagy hasonló szervezeti egység egyetlen megkérdezett vállalatnál sem volt, a feladatok általában az emberi erőforrás és az IT te- 
A tudásmenedzsment program helyzete a vállalatoknál (adott választ megjelölők százalékában)

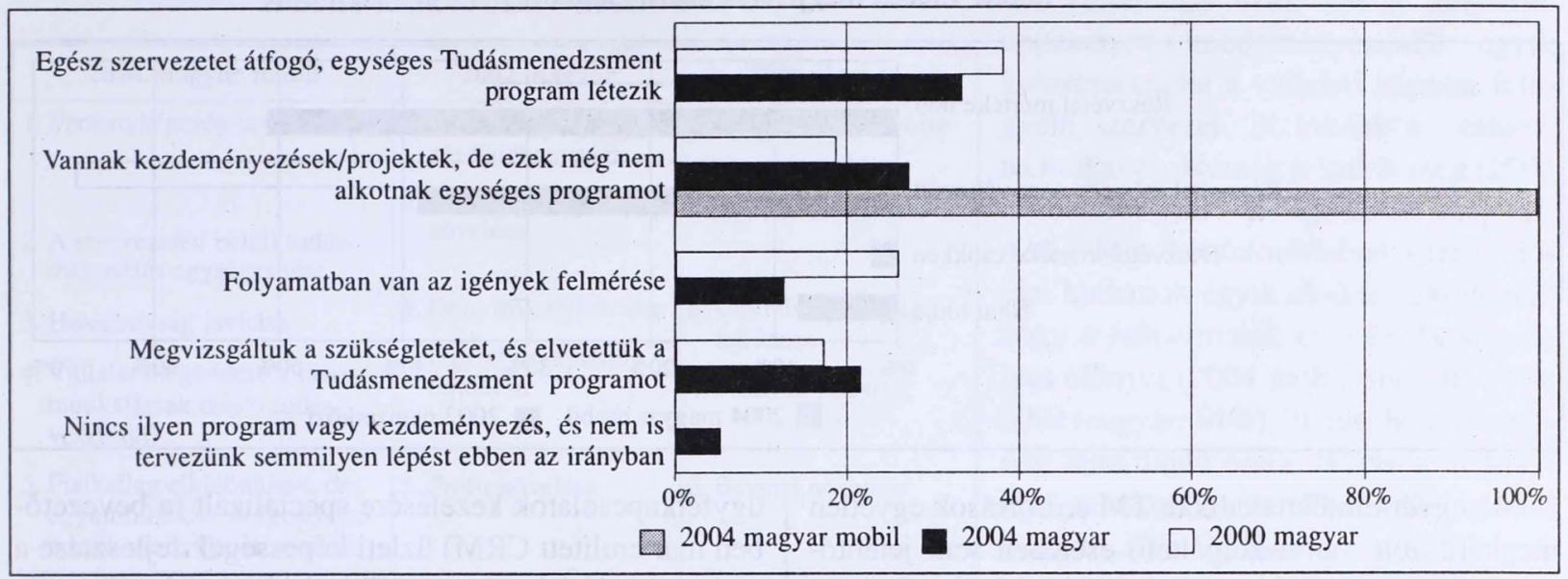

A felső vezetés szerepe a tudásmenedzsment tevékenységekben (adott választ megjelölők százalékában)

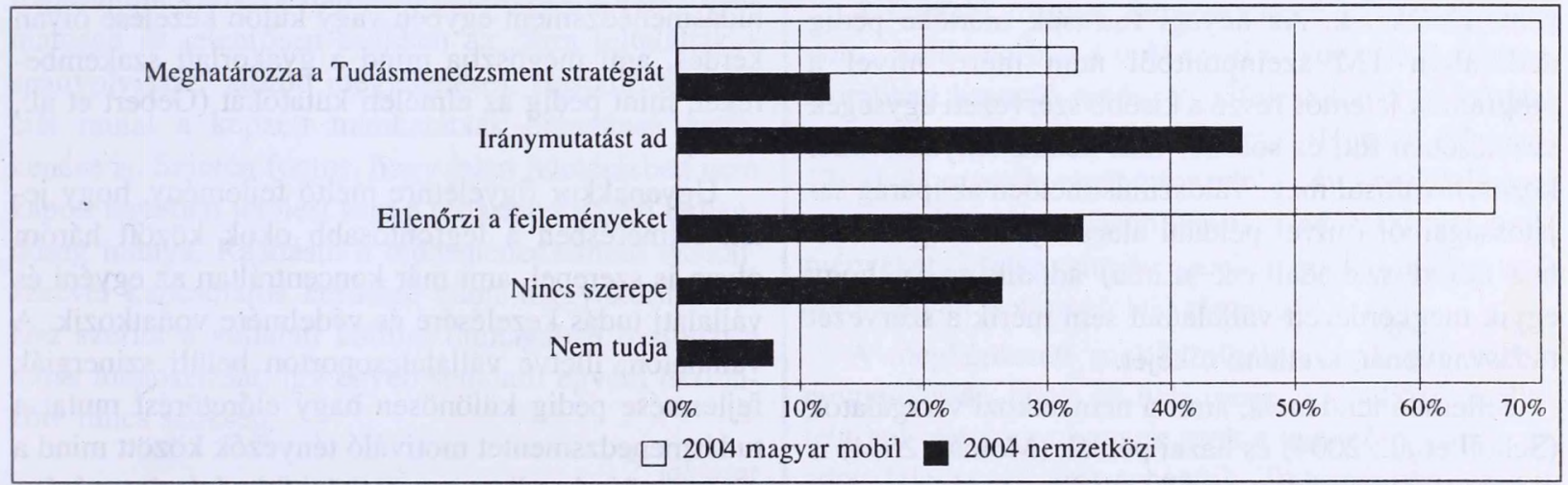

rület között oszlanak meg. Természetesen ezzel együtt jár az is, hogy a három válaszadó egyikénél sincs - a külföldön, főleg a TM korai fellendülésekor létrehozott - formális tudásért felelős vezérigazgató-helyettesi vagy igazgatósági tanácstagsági poszt („Chief Knowledge Officer").

A létező TM programok sem alkotnak egységes, átfogó rendszert, mindhárom megkérdezett létező, de a szervezeti egységeknél jórészt önállóan futó kezdeményezésekről számolt be (1. ábra).

Figyelemre méltó különbség rajzolódik ki, ha a TM akciók kezdeményezőire vonatkozó válaszokat vizsgáljuk a felmérések sorában. A 2000-es vizsgálatok eredményei szerint döntően a vezetői szintek (felső, senior, illetve középvezetők) a kezdeményezők mind a magyar (88\%), mind pedig a nemzetközi (84\%) felmérés szerint. A 2002-es magyar felmérésben már csökkent (81\%) ez az arány. A 2004-es mobiltávközlési felmérésben pedig már jelentős mértékű alulról jövő kezdeményezésekről számoltak be, amikor is a munkatársak saját (osztályuk/igazgatóságuk) igényeiknek megfelelő tudásmenedzsment elemek bevezetését indították/valósították meg.

A magyar mobiltávközlési szolgáltatóknál egyre erősödő az a tendencia is, amikor az anyavállalati globális kezdeményezések részeként vezettek be valamilyen rendszert a hazai leányvállalatnál. Ez nemcsak a sokszor példaként említett elektronikus oktatási rendszereket érinti (amelyek a 2003-2004-es esztendő fő fókuszának tekinthetők mindhárom vállalatnál az emberi erőforrás fejlesztés területén), hanem tudásmenedzsment eszközöket is (pl. globális gyakornoki tapasztalatcserét lehetővé tévő elektronikus fórumok).

A felső vezetés ugyanakkor nem marad ki a döntésekből, szerepe a stratégia meghatározására és a fejlemények ellenőrzésére koncentrálódik (2. ábra), a részvétel mértéke nem csökken, sôt néhol nő (3. ábra). 
A felső vezetés szerepének változása a tudásmenedzsment tevékenységekben (adott választ megjelölők százalékában)

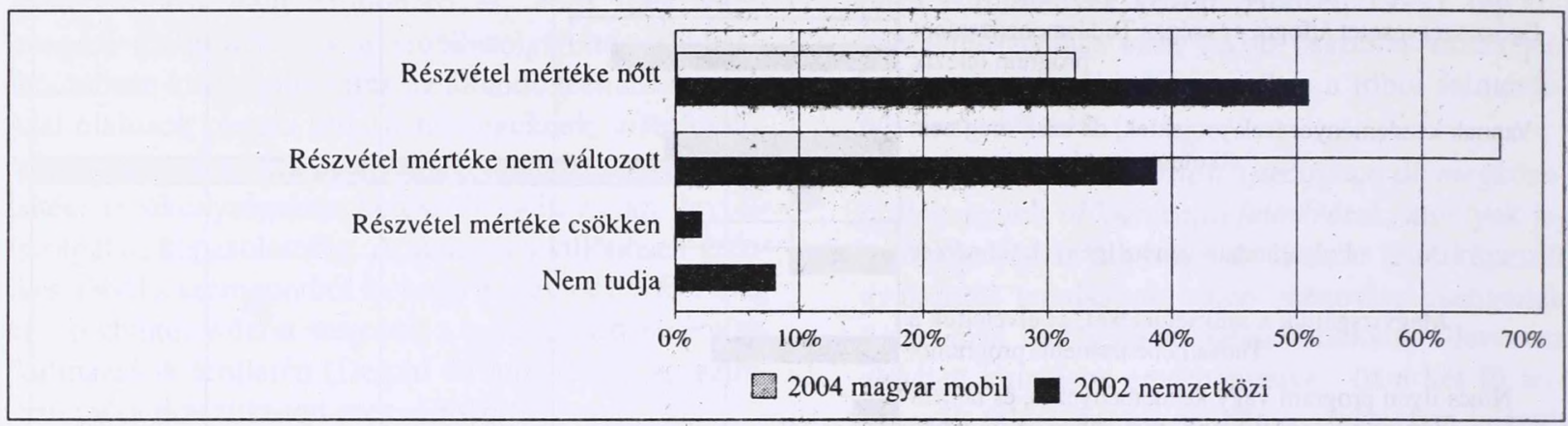

Az egyértelmúen dedikált TM erőforrások egyetlen megkérdezett mobilszolgáltató esetében sem jelentősek. A kijelölten ezért a feladatkörért felelős alkalmazottak száma mindenhol néhány fő, és sok tevékenység szervezeteknél elszórva, részmunkaidős feladatként jelentkezik. Az anyagi források mértéke pedig dedikáltan TM szempontból nem mért, mivel a programok jelentős része a kisebb szervezeti egységek kezelésében fut, és sokszor más kezdeményezésekkel közösen valósul meg. Valószínűsíthetően az iparág sajátosságaiból (mivel például alacsony a szolgáltatókhoz kötött szabadalmak száma) adódik az is, hogy egyik megkérdezett vállalatnál sem mérik a szervezet tudásvagyonát, szellemi tőkéjét.

Jellemző tendencia, amit a nemzetközi vizsgálatok (Scholl et al., 2004) és hazai példák (Molnár, 2004) is visszaigazolnak, hogy az IT centrikus tudásmenedzsmentet felváltja a sokkal inkább emberközpontú gondolkodásmód. Gyakorlatilag minden szükséges informatikai rendszer rendelkezésre áll (ami nem jelenti a technikai problémák hiányát, mint az később látható lesz) a megkérdezett három vállalatnál, a fő fókusz pillanatnyilag a részvétel növelésén van, mert a rendelkezésre álló eszközök használati kultúrája elsősorban passzív és nem aktív (azaz a tudás dolgozók közti megosztása szenved hiányosságokat).

\section{A tudásmenedzsment mozgatórugói}

A TM kezdeményezések indítása mögött megbújó indokok sok hasonlóságot, de eltéréseket is mutatnak a különböző felmérésekben (1. és 2. táblázatok). Látszólag a pénzügyi és ügyfélközpontú fogalmak súlya csökkent, de ezek inkább csak átalakulnak. Egyrészt a versenyképesség és hatékonyság magában foglalja ezeket a fogalmakat is. Másrészt az ügyfélkapcsolatok kezelésére specializált (a bevezetőben már említett CRM) üzleti képességek fejlesztése a mai távközlési iparban önálló, óriási kezdeményezés minden vállalat részéről, amit nem tekintenek a szorosan vett tudásmenedzsment részének. (A CRM és a tudásmenedzsment egyben vagy külön kezelése olyan kérdés, ami megosztja mind a gyakorlati szakembereket, mint pedig az elméleti kutatókat (Gebert et al., 2003).

Ugyanakkor figyelemre méltó fejlemény, hogy jelen felmérésben a legfontosabb okok között három olyan is szerepel, ami már koncentráltan az egyéni és vállalati tudás kezelésére és védelmére vonatkozik. A vállalaton, illetve vállalatcsoporton belüli szinergiák fejlesztése pedig különösen nagy előretörést mutat a tudásmenedzsmentet motiváló tényezők között mind a magyar, mind pedig a nemzetközi felmérések tanúsága szerint is.

\section{Tudásmenedzsment problémák}

A tudásmenedzsment eszközök és gyakorlatok bevezetésével kapcsolatos problémák a 3. táblázatban láthatóak. A tudásmenedzsment előnyeinek ismerete és az információdömping említése mindhárom magyar felmérésben magas arányt kapott. Különösen érdekes ez akkor, ha abból a szemszögből közelítjük, hogy a tudásmenedzsment egyik célja, hogy rendszert vigyen a feladatok ellátásához szükséges tudások és információk tengerébe. Így ez a két probléma vagy a tudásmenedzsment kezdeményezéseket megelőző igényfelmérési fázis, vagy pedig a bevezetéshez kapcsolódó kommunikációs teendők hiányosságára utal.

Több olyan tétel is van, ami a korábbi magyar általános felmérésekben mágas jelölési arányt kapott, míg a 2004-es mobilszektori válaszadók egyike sem 
1. táblázat es mobilpiaci magyar felmérés esetében

A tudásmenedzsment programok elindításának fő okai - nemzetközi

\begin{tabular}{|l|l|l|}
\hline \multicolumn{1}{|c|}{2004 magyar mobil } & \multicolumn{1}{|c|}{2002 magyar } & \multicolumn{1}{c|}{2000 magyar } \\
\hline 1. Versenyképeség javítása & $\begin{array}{l}\text { 1. Javul a munkavég- } \\
\text { zés hatékonysága } \\
\text { 2. Versenyelőny } \\
\text { növelése }\end{array}$ & 1. Dolgozók fejlesztése \\
$\begin{array}{l}\text { 2. A szervezeten belüli tudás- } \\
\text { megosztás egységesítése }\end{array}$ & 2. Marketing \\
$\begin{array}{l}\text { 3. Hatékonyság javítása } \\
\begin{array}{l}\text { 4. Vállalat megvédése a távozó } \\
\text { munkatársak miatti tudás- } \\
\text { vesztéstől }\end{array}\end{array}$ & $\begin{array}{l}\text { 4. Ügyfél orientáltság } \\
\text { fejlôdése }\end{array}$ & $\begin{array}{l}\text { 3. Ügyfélorientáltság } \\
\text { fejlődése }\end{array}$ \\
$\begin{array}{l}\text { 5. Fizikailag elkülönülten, de } \\
\text { együttmúködve dolgozó cso- } \\
\text { portok munkájának segítése }\end{array}$ & 5. Profit növelése & 5. Bevétel növelése \\
\hline
\end{tabular}

ezek egyáltalán nem merültek fel egyetlen vállalatnál sem, sőt a tudásmenedzsment kezdeményezések egyik kulcsszereplője a vállalati képzést felügyelő szervezet. Itt inkább a „valódi” technikai problémák jelentek meg (2004 mobil magyar: 67\%; 2002 magyar: $42 \%$ ). Mindkét felmérésben a technológiai kudarcok egyik okaként említették, hogy a felhasználók nem látták személyes előnyét (2004 mobil magyar: 33\%; 2002 magyar: 64\%), illetve, hogy a rendszer nem tudott beilleszkedni a megszokott munkafolyamatokba (2004 mobil magyar: 33\%; 2002 magyar: 51\%). jelölte problémának. Az egyik ilyen fontos fejlemény, hogy a tudásmenedzsment egyre inkább elfogadott fogalommá válik (a három felmérési év során folyamatosan és jelentősen csökken az ,újra feltalálták a spanyolviaszt" attitűd megjelenése). Hasonló tendenciát mutat a képzett munkatársak hiányának csökkenése is. Szintén fontos, hogy jelen felmérésben nem kapott egyetlen jelölést sem a tudásmegosztási hajlandóság hiánya. Ráadásul a tudásmenedzsment ösztönzésével kapcsolatos kérdésre adott leggyakoribb válasz szerint a vállalati kultúra önmagában ösztönzi a tudás megosztását, így egyéb standard egyéni ösztönzőre nincs szükség.

2. táblázat

Tudásmenedzsment problémák okai (adott választ megjelölők százalékában)

\begin{tabular}{|c|c|}
\hline 2002 nemzetközi & 2000 nemzetközi \\
\hline $\begin{array}{l}\text { 1. Egységek közötti szinergiák } \\
\text { kihasználása }\end{array}$ & $\begin{array}{l}\text { 1. Versenyelôny növelése } \\
\text { 2. Marketing }\end{array}$ \\
\hline $\begin{array}{l}\text { 2. Ügyfeleknek nyújtott } \\
\text { értékek növelése }\end{array}$ & $\begin{array}{l}\text { 3. Ügyfél orientáltság } \\
\text { fejlổdése }\end{array}$ \\
\hline 3. Minőség javítása & 4. Profit növelése \\
\hline 4. Költségek csökkenése & 5. Bevétel növelése \\
\hline $\begin{array}{l}\text { 5. Fejlesztések/innováció } \\
\text { gyorsítása }\end{array}$ & tes \\
\hline
\end{tabular}

Jelentős különbség van azonban a technológia problémák részleteiben, amelyre külön további kérés is vonatkozott a kérdőívben. A 2002-es magyar felmérés jelentős problémákat mutatott a tréning esetében, ugyanis az akkori válaszadók több mint fele jelezte a kudarcok okának a tréner alkalmatlanságát (57\%), vagy a tréning komolyan nem vételét (56\%). A 2004-

\section{Tudásrések}

A korábbi magyar felmérésekhez képest új elem volt a kérdéssorban a tudásrésekre vonatkozó fejezet. Korábban hasonló módszert kifejezetten a távközlési cégekre már alkalmazott Thomas Housel (Housel, 1999), de az azóta eltelt 6 forradalmi év a távközlésben gyakorlatilag összehasonlíthatatlanná teszi az eredményeket. Utalás szintjén azonban jelezni fogom az ő eredményeit is a megfelelő részeknél.

A megkérdezett mobilszolgáltatóknak azt kellett megjelölniük, hogy az üzletmenet különböző területein hol, mennyire nagyok azok a tudásrések, amik az adott feladat ellátását nehezítik. Tudásrés nem csak a tudás hiánya lehet, hanem a meglévő tudás nem megfelelő rendezettsége vagy kihasználtsága is. Mivel a válaszok a már felismert tudásréseket térképezik fel, nem meglepő, hogy mindhárom vállalat azt nyilatkozta, hogy a rések bezárására az adott szervezeti területeken már futnak projektek. (Ezeket a kezdeményezéseket azonban jórészt különállóan valósítják meg.) A tudásrések nagyságára vonatkozó válaszok a 4. ábrán láthatók.

A legmarkánsabban megfigyelhető jelenség, hogy egyetlen terület (marketing) kivételével a jövőbeli megítélés átlaga minden esetben pozitívabb a jelenleginél, azaz a cégek véleménye szerint a futó projektek vagy csökkenteni fogják, vagy legalább nem hagyják növekedni a tudásrések nagyságát. (Ez nem jelenti azt, hogy az egyedi válaszok esetében egy-egy vállalatnál valamely más faktoroknál ne lett volna a jövőre nagyobb rés-érték jelölve, de ez a három vállalat átlagában már nem mutatkozott meg.) 
A tudásmenedzsment problémák okai (adott választ megjelölők százalékában)

\begin{tabular}{|l|c|c|c|}
\hline Probléma & $\begin{array}{c}\mathbf{2 0 0 4} \text { mobil } \\
\text { magyar }\end{array}$ & $\begin{array}{c}\mathbf{2 0 0 2} \\
\text { magyar }\end{array}$ & $\begin{array}{c}\mathbf{2 0 0 0} \\
\text { magyar }\end{array}$ \\
\hline A TM előnyök ismeretének hiánya & 67 & 60 & 86 \\
\hline Információdömping & 67 & 46 & 50 \\
\hline Nincs idő a tudás megosztására & 33 & $\mathbf{5 3}$ & $\mathbf{7 8}$ \\
\hline A fejekben lévő tudást nehéz megszerezni & 33 & 69 & 73 \\
\hline Technológia hiánya & 33 & 25 & 44 \\
\hline Újira feltalálták a spanyolviaszt & 0 & 38 & 67 \\
\hline A munkatársak nem akarják megosztani tudásukat & 0 & 52 & 61 \\
\hline A dolgozók nem használják a technológiát & 0 & 48 & 53 \\
\hline Képzett munkatársak hiánya & 0 & 23 & 50 \\
\hline Nincs megfelelő szponzor & 0 & 52 & 50 \\
\hline Nehéz megtalálni a szükséges tudást & 0 & 38 & 50 \\
\hline Eltérố technológia a szervezet különböző pontjain & 0 & 32 & 45 \\
\hline A vezetőség nem elkötelezett & 0 & 71 & 43 \\
\hline Nincs megfelelő tudás & 0 & 34 & 27 \\
\hline K+F-re kevés pénz jut & 0 & 51 & 19 \\
\hline Nincs pénz (eróforrás) a tudás megosztására & & 59 & \\
\hline A TM hatásköri villongásokhoz vezet & & 43 & \\
\hline A vállalati kultúra nem támogatja & 63 & \\
\hline
\end{tabular}

3. táblázat színűbb, hogy az amerikai és magyar vál--lìv lalati méretek és kultúra közti különbségek ‘्र९g: okozzák az eltérést.

$\mathrm{Az}$ iparág egyik fontos sajátosságára sib̀c mutat rá, hogy már Housel felmérésében is zi n: közepesen magas pontszámot kaptak az új ì̀ $s$ termékfejlesztéssel kapcsolatos területek 궈 (igény-előrejelzés, támogatás), ami a gyors әтоҮ távközlési technológia és szolgáltatási iə⿳亠े fejlődés folyamatosságát tükrözi.

\section{Külső tudásforrások}

A tudásmenedzsment hatáskörébe эdò nemcsak a belső tudás kezelése tartozik be- - le, ezért külön kérdéskör foglalkozott a $\mathrm{s}_{\mathrm{j}}^{\mathrm{j}}$ külső források kezelésével. Az 5. ábra tar- -iBJ talmazza e források felhasználásának fő òł okaira vonatkozó válaszok összefoglalását. Jjs̀zi Az első észrevétel rögtön az lehet, hogy a $\mathrm{b}$ ₹ külső tudásforrások használata több szem- -ms pontból is fontos, elsősorban a gyors piaci iosi

A két legkomolyabb tudásréssel rendelkező terület az értékesítés és a marketing lett. A magyar mobil piacon uralkodó ádáz versenyhelyzetet tekintve ez nem is meglepő, sőt további közvetlen versenytényezők (versenytárs információk, ügyfélkezelés és új szolgáltatási igények előrejelzése) is közepesen magas pontszámot kaptak. Legalacsonyabb tudásrés fokozat mind a jelen, mind pedig a jövő esetében a számlázásnál és a szervezeti tudásnál mutatkozott. Ez különösen érdekes abból a szempontból is, hogy Housel felmérésében a távközlési cégek által megjelölt legnagyobb tudásrések között a szervezeti tudás, $\mathrm{az}$ internetes tarifarendszerek és számlázás kialakítása is ott volt. A felmérés óta eltelt idő alatt a számlázási struktúrával és technológiával kapcsolatos problémák csökkenése nem meglepő, hiszen a tarifarendszerek kiforrottak (bár egyszerűsödni nem biztos, hogy egyszerűsödtek, de mindenképpen ismertebbé és szabványosabbá váltak bizonyos modellek) és a támogató rendszerek is sokat fejlődtek. A szervezeti tudás réseinek csökkenését azonban nehéz lenne pusztán az eltelt idővel magyarázni, való- igényekhez való alkalmazkodás miatt, de azért is, mert az így megszerzett tudás túl széles, mély vagy drága lenne a belső fejlesztéshez. Ezek a faktorok mind jól beleillenek a gyors technológiaváltási ciklusokkal terhelt mobiltávközlés képébe, hiszen az új technológiák

Tudásrések a különböző üzleti területeken

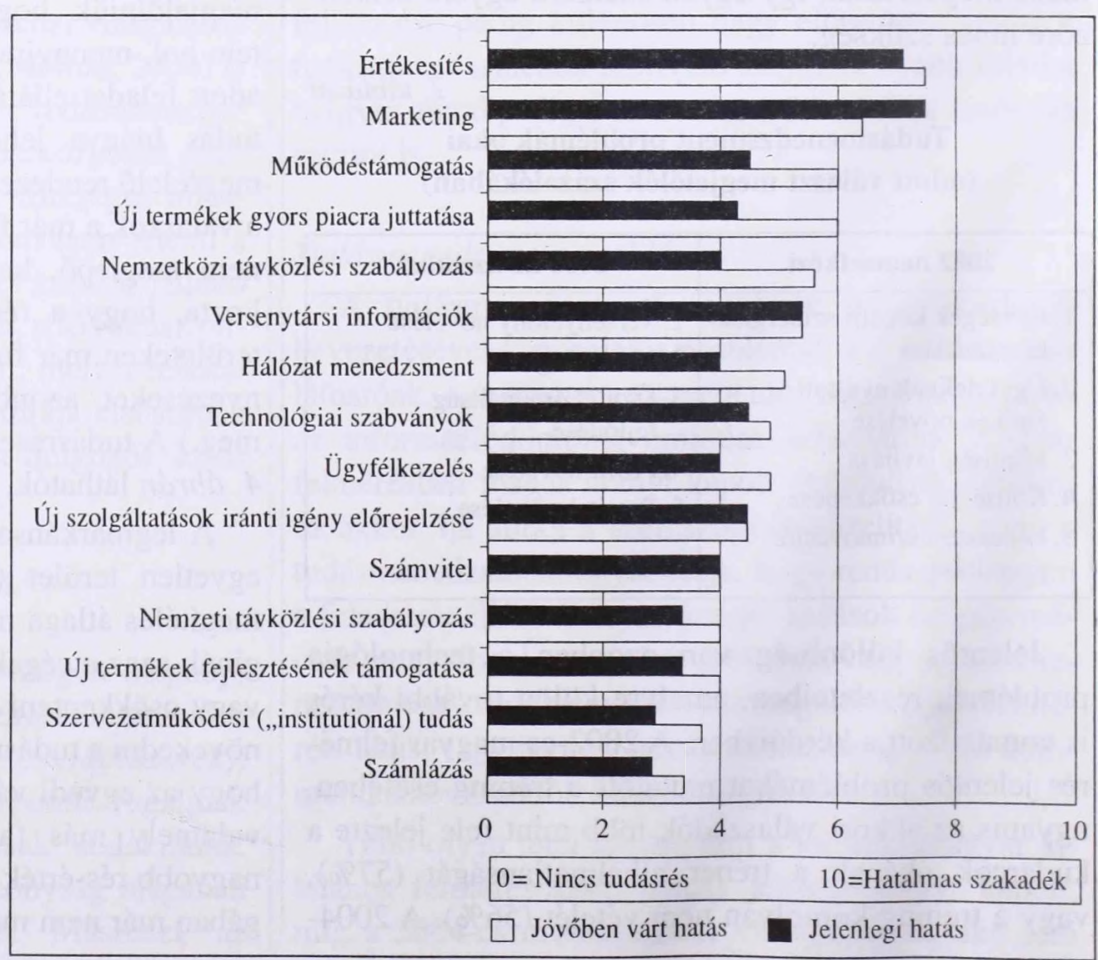


belső elsajátítása nemcsak sok időt venne igénybe, de a megtérülés is kétséges az újabb és újabb fejlesztések megjelenésekor fellépő, előbb-utóbb elkerülhetetlen elavulással. Az OECD 2002-es általános iparági felmérésében (Edler, 2002) ugyan szintén a gyors reagálás került az élre, viszont ugyanolyan fontossággal második helyre a megfelelő belső személyi erőforrás hiánya került. (Ez alátámasztani látszik Németország lépéseit a külföldi képzett munkaerő becsábítására pl. a sokszor emlegetett indiai informatikusok fogadásának esete.)

Érdemes megvizsgálni továbbá, hogy melyek a legfontosabb bevont külső tudásforrások (6. ábra). A legfontosabbnak ítélt forrás a vállalati szövetségek, ami elsősorban a magyar mobilszolgáltatók külföldi anyavállalatainak (illetve az azok által kötött, globálisan érvényes együttmúködési megállapodásoknak) köszönhető. A klasszikusnak nevezhető szakirodalom fontossága mellett magas pontszámot kapott továbbá az internet. Ez utóbbinak legszélesebb körű a felhasználása, a piaci információtól egészen a technológiaszabványokig terjed.

\section{5. ábra}

Külső tudásforrások használatának okai

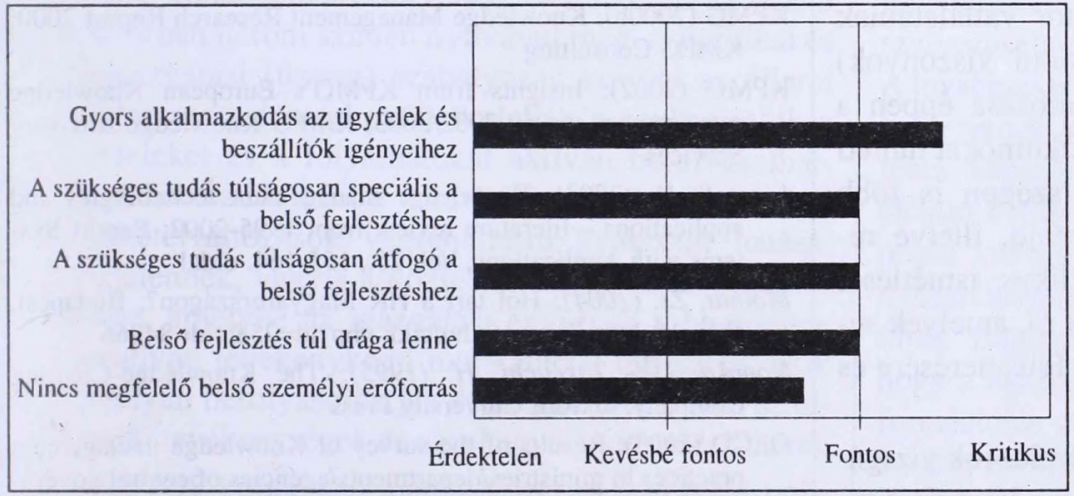

6. ábra

A különböző külső tudásforrás típusok fontossága

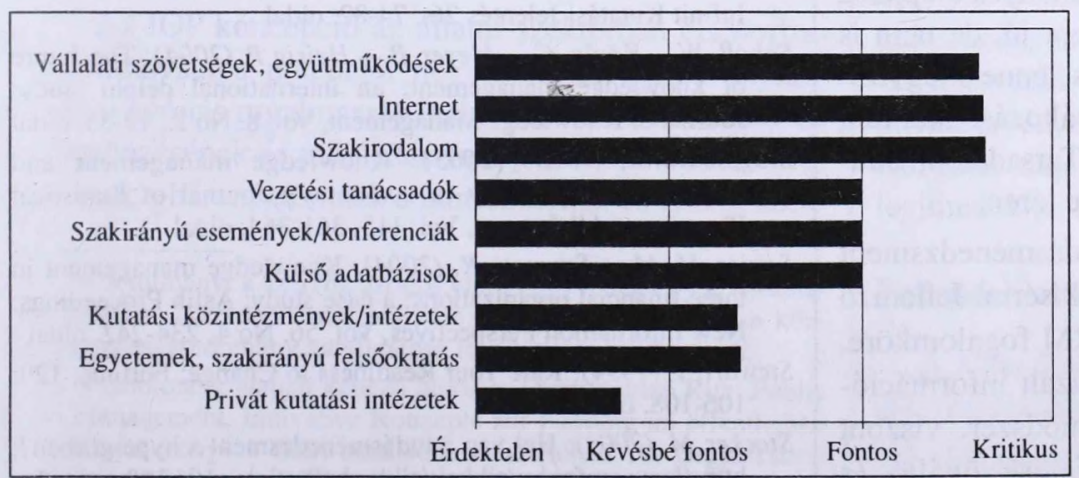

A már említett németországi $\mathrm{OECD}$ felméréshez képest a legmarkánsabb eltérés, hogy ott és akkor a vezetési tanácsadók és a vállalati kapcsolatok alacsony fontossági kategóriába kerültek, míg a legfontosabbak a szakirodalom, a konferenciák és az internet voltak (utóbbi három viszonylag magas pontszámot kapott a 2004-es magyar mobil felmérésben is).

A felsőoktatási intézmények a német felmérésben közepes fontosságot kaptak, ami magasabb ugyan a jelen magyar eredményeknél, de ez valószínüsíthetően szintén a rendkívül gyors távközlési változásoknak tudható be (ahogyan az egyik iṕarági szereplő megfogalmazta: a mobilszolgáltatók is évekkel vannak lemaradva a készuilékgyártóktól, az egyetemek pedig néhány kivételes labor esetében - közös kutatások eredményeként vagy a készülékgyártók szintjén vannak, vagy döntő többségükben inkább csak sodródnak a fejleményekkel). Fontos lépés azonban, hogy léteznek az egyetemek és a vállalatok közötti együttműködések, ezek fontossága azonban még jelentősen elmarad a legfontosabb külső tudásforrásoktól. Megjegyzésre méltó továbbá, hogy mindkét felmérésben a legalacsonyabb fontossági pontszámot a privát kutatási intézetek kapták. (Ez lehet valamiféle európai jelenség is, hiszen az Egyesült Államokban a magánkézben lévő kutatási intézetek sokkal nagyobb jelentőséggel bírnak.)

\section{Összefoglalás, következtetések és következő lépések}

Az eredmények alapján elmondható, hogy a magyar mobiltávközlési szolgáltatók jelentős lépéseket tettek már meg a tudásmenedzsment területén. Rendelkezésre állnak több területen a szükséges informatikai eszközök és az emberi oldal sem elhanyagolt. A korábbi magyar általános felmérésekhez képest jelentősen kedvezőbb, fejlettebb képet mutatnak a mai mobilszektor eredményei. $\mathrm{Az}$ iparág problémáit ismerve fontos szempont, hogy a tudásmenedzsment kezdeményezéseket egyértelműen a versenyelőny biztosításához szükséges egyik eszköznek tekintik 
a vállalatok. Ugyanakkor ezek a különálló projektek még nem értek össze vállalati szintű, egységes programmá. Kevés a kifejezetten tudásmenedzsment projektekhez egyértelműen dedikált forrás, ami nem feltétlenül negatívum, csak azt mutatja, hogy ezt a szakterületet nem önálló vállalati entitásként kezelik, hanem az üzleti folyamatok (a cég területén elszórtan múködő) támogatójaként tekintenek rá. Ezt a tendenciát támasztja alá az is, hogy különálló tudásmenedzsment szervezet és vezető nincs a megkérdezett cégnél. Az egyik legfontosabb kérdés a jövőre nézve az, hogy a tudásmenedzsment kezdeményezések összehangolása az információtechnológia vagy az emberi erőforrás dominanciájával kerül-e megvalósításra, mert ez alapvetően meghatározza a fejlesztési irányokat és a bevezetési stratégiákat.

A tudásmenedzsment felmérések a korábbi általános (különböző iparágakat átfogó) szemléletből egyértelműen a szektorspecifikus kutatás felé haladnak. Ennek legfontosabb okai könnyen beláthatók már akkor, ha csak arra gondolunk, hogy mennyire más egy innovatív szektor igénye ezzel a területtel kapcsolatban, mint egy folyamatos fejlesztést ritkán és kisebb mértékben igénylő ágazaté. Jelentős különbségek adódhatnak az adott gazdasági szektor vállalatainak összetétele (számosság, méret, tulajdoni viszonyok) nyomán is. Ezen eredmények összemosása éppen a legfontosabb eltéréseket, illetve specifikumokat tünteti el. Ezért remélhető, hogy Magyarországon is több iparág-specifikus felmérés születik majd, illetve remélhető, hogy e vizsgálatok periodikus ismétlései olyan belső folyamatokra mutathatnak rá, amelyek segíthetnek a problémák időben történő felismerésére és a korrekciók javaslatára.

Nemcsak az ipari és kereskedelmi szektorok vizsgálata hozhat érdekes tanulságokat, hanem a közszféra tudásmenedzsment gyakorlatainak elemzése is, ahogyan ezt az OECD is tette 2002-ben (OECD, 2003). Ebben a felmérésben hazánk az összesített eredmények alapján a középmezőny aljában végzett, ami nem jó, de nem is elkeserítő eredmény, viszont érdemes lenne megvizsgálni, hogy az azóta eltelt időszak - változásokkal teli, beleértve az új Nemzeti Információs Társadalom Stratégiát is - milyen változásokat hozott e téren.

Végezetül rendkívül fontos a tudásmenedzsment hatáskörének változását figyelemmel kísérni. Jellemző példa a már bevezetőben említett CRM fogalomköre, ami valójában egy jelentősen specializált információés tudásmenedzsment rendszer és módszer, viszont mára sajátosságaira tekintettel kezelése önálló (a szolgáltató ágazatokban akár nagyobb prioritással is, mint az általános tudásmenedzsment). Kérdés, hogy a jövőben a tudásmenedzsment mint a haladó, specializált új eljárások inkubátora kap-e szerepet (amelyek megerôsödve már önálló üzletággá fejlődnek), vagy megtartja az átfogó és összefogó szerepét?

\section{Felhasznált irodalom}

Delphi Group (1998): Survey of KM practice in USA; összefoglaló megtekinthető: http://choo.fis.utoronto.ca/UvA/ Kmsurvey/default.html

Edler, J. (2002): OECD Survey on Knowledge Management German Pilot Study; OECD, http://www.oecd.org/dataoecd/ 22/61/2756278.pdf

Fehér, P. (2002): Tudásmenedzsment: problémák és veszélyek; Vezetéstudomány, 4.szám, 36-45. oldal

Gebert, H., - Geib, M., - Kolbe, L. - Brenner, W. (2003): Knowledge Enabled customer relationship management; Journal of Knowledge Management, Vol. 7. No 5., 107-123. oldal

Housel, T. (1999): Knowledge Management for the Telecommunications Industry; International Engineering Consortium

Hwang, G. H. (2003): Information and communication technologies and changes in skill, International Journal of Manpower, Vol 24. No. 1., 60-82. oldal

KPMG (2000a): Tudásmenedzsment felmérés Magyarországon; KMPG Consulting

KPMG (2000b): Knowledge Management Research Report 2000; KMPG Consulting

KPMG (2002): Insights from KPMG's European Knowledge management survey 2002/2003; KMPG Knowledge Advisory Services

Liao, S. H. (2003): Knowledge management technologies and applications - literature review from 1995-2002; Export Systems with Applications, Vol. 25., 155-164. oldal

Molnár, Zs. (2004): Hol tart a HR Magyarországon?; Budapest, Figyelô, http://www.fn.hu/cikk.php?id=25\&cid=84966

Nonaka, I. - Takeuchi, H. (1995): The Knowledge-Creating Company; Oxford University Press

OECD (2003): Results of the survey of Knowledge management practices in ministries/departments/agencies of central government; OECD public governance and territorial development directorate, http://www.oecd.org/dataoecd/59/8/33709748.doc

Schneider, H. (2004): Nemzetközi tapasztalatok az új technológiákhoz kapcsolódó munkahelyi tudásjelenségekrổ, ITTK Infinit Kutatási Jelentés 26., 74-82. oldal

Scholl, W. - König, C. - Meyer, B. - Heisig P. (2004): The future of knowledge management: an international delphi study; Journal of Knowledge Management, Vol. 8. No 2., 19-35. oldal

Singpurwalla, N. D. (2003): Knowledge management and information superiority (a taxonomy); Journal of Statistical Planning and Inference, Vol. 115, 361-364. oldal

Squier, M. M. - Snyman, R. (2004): Knowledge management in three financial organizations: a case study; Aslib Proceedings: New Information Perspectives, Vol. 56. No 4, 234-242. oldal

Stewart, T. (1994): Rate Your Readiness to Change; Fortune, 129: 106-108. oldal

Stocker, M. (2003): Hol van a tudásmenedzsment a hype görbén?; http://www.mfor.hu/cikkek/cikk.php?article=10174\&page $=1$ 